\title{
THE INFLUENCE OF CAPITAL ADEQUACY RATIO AND NON-PERFORMING LOAN ON PROFITABILITY OF COMMERCIAL BANKS LISTED ON THE INDONESIA STOCK EXCHANGE IN 2017 - 2019
}

\author{
Nathaniel Karel DJAYA \\ Multimedia Nusantara University, Indonesia \\ nathaniel.karel@student.umn.ac.id \\ Ika YANUARTI \\ Multimedia Nusantara University, Indonesia \\ ika_y@umn.ac.id
}

\begin{abstract}
This study has the purpose to analyze the influence of Capital Adequacy Ratio and Non-Performing Loan on profitability of Commercial Banks. The sample of this study consists of 26 Commercial Banks listed on the Indonesia Stock Exchange in 2017 - 2019. This research used Multiple Regression Analysis to analyze the data gathered from audited financial reports of those banks. The results showed that the Capital Adequacy Ratio and NonPerforming Loan simultaneously affect the Profitability, which means that if there is an increase in Capital Adequacy Ratio and Non-Performing Loan, then it will be followed by an increase in Return on Assets. However, if it's tested partially then it is only Non-Performing Loans that affect the Return on Assets. The influence was negative and statistically significant. The Capital Adequacy Ratio had positive influence on Return on Assets but not statistically significant.
\end{abstract}

Keywords: Capital Adequacy Ratio; Non-Performing Loan; Return on Assets.

DOI: https://doi.org/10.24818/beman/2021.11.4-06

\section{INTRODUCTION}

One indicator to measure the country economic growth is GDP (Gross Domestic Product), which is the total added value of all business units in a country and also the total value of final goods and services produced from the economic unit. Indonesia economic growth showed an increase from 2017 to 2019 . There was an increase of $8.41 \%$ from 2017 to 2018 and an increase of $6.29 \%$ from 2018 to 2019 . However, in 2020 it has decreased by 2,52\%, which was due to the spread of the corona virus (bps.go.id). The movement of GDP is followed by the movement of credit distribution to third parties, which shows that there is a contribution 
from the banking sector to economic growth. This can be seen from the existence of lending activities to third parties which have three objectives, such as consumption needs, investment needs, and working capital needs. According to the Law No. 10 / 1998 issued by the President of Republic of Indonesia about banking, a bank is a business entity that collects funds in the form of deposits and distributes the collection of funds to the public in the form of credit and or others with the aim of improving the standard of living of the people. The COVID-19 pandemic tends to have a negative influence on the banking industry, where the industry experiences an increase in credit risk due to defaults experienced by debtors which makes bank businesses tend to reduce lending activities to third parties (kontan.co.id, 2021). This is also supported by finansial.bisnis.com (2021), that credit growth in the banking industry decreased by $2.41 \%$ at the end of 2020.

In COVID-19 pandemic, commercial banks are still in a stable condition (ojk.go.id, 2020). This can be observed in terms of good capital through the CAR ratio of $23.81 \%$, which shows that the banking industry has a high ability to manage capital in reducing business risk. However, there was a decline in the intermediation function, particularly in lending due to a contraction in credit growth. However, there is a high growth of third party funds of $11.11 \%$, so it is necessary to pay attention to the increase in credit risk and also the level of profitability during this time. Conventional commercial banks are banks that carry out their business activities conventionally where the profit system used is the interest system from saving and or loan, while islamic commercial banks are banks that carry out business activities with sharia principles where the profit system used is a profit sharing system from fundraising, financing, and others.

Between the two types of commercial banks, there is one type of commercial bank that is consistent with the commercial bank industry itself, such as conventional commercial banks, where credit risk in conventional commercial banks must also be the center of attention and also the level of profitability from the previous year. In conventional banks, many banks are based on the aspect of ownership, such as Government- Owned Banks are banks in which the deed of establishment and capital are owned by the Indonesian state government, where all profits obtained are also owned by the government, such as Bank Mandiri, Bank Tabungan Negara, Bank Rakyat Indonesia, Bank Negara Indonesia, and others. National Private Owned Banks are mostly owned by national private parties and the deed of establishment was established by private parties, and the profits obtained by these banks are also owned by national private parties, such as Bank Central Asia, Bank CIMB Niaga, Bank Danamon, Sinarmas, and others. Mixed-Owned Banks, which have a background that share ownership of the bank is owned by foreign parties and national private parties, but most of them are held by Indonesian citizens, such as Bank Agris, Commonwealth Bank, Woori Indonesia Bank, ANZ Bank Indonesia, and others (Kasmir, 2016). 
As example, there are two commercial bank companies that experienced a decline in loans distribution due to the COVID-19 pandemic, such as PT Bank Central Asia Tbk (BBCA), where the demand for loans distributed decreased by $0.6 \%$ from Rp 585.39 trillion to Rp 581.9 trillion in the 3rd quarter of 2020 based on certain segments, such as commercial and SME loans which decreased by $4.9 \%$ from Rp 191.65 trillion to Rp 182.7 trillion, then the consumer loan portfolio decreased by $9.4 \%$ from Rp 155.02 trillion to Rp 141.7 trillion (ekonomy.okezone.com, 2020). And then continued with PT Bank Maybank Indonesia Tbk (BNII), where in 2020 , credit distribution decreased by $14.6 \%$ from Rp. 132.59 trillion to Rp. 115.7 trillion, which caused an increase in the value of credit risk from 3.65\% to $4.9 \%$ (keuangan.kontan.co.id, 2020). However, this is different from the two commercial banks above, such as PT Bank Mandiri Tbk (BMRI), which stated that after lending from these businesses, they experienced a positive growth of $3.79 \%$ from Rp 841.82 trillion to $\mathrm{Rp} 873.73$ trillion. This is shown in the third quarter of 2020, as increase in lending came from productive loans consisting of working capital and investment which grew by 3.88\% from Rp 593.35 trillion to $R p 616.37$ trillion.

Profitability is one of the important indicators in assessing the performance of a company. In this study, profitability is measured by using ROA (Return on Assets), because bank Indonesia prioritizes ROA ratio, where the value of assets obtained comes from third party funds. This ratio is important for bank businesses, because it can measure the level of efficiency owned by the management in utilizing company assets to generate profits (Haryanto, 2016). With a greater ROA value, the company is able to take advantage of a number of assets owned, so companies can produce higher profitability (Kumbirai \& Webb, 2010, in Javaid \& Alalawi, 2018). According to Majidi (2017), there are three main components of bank performance indicators that are very important for smoothness in carrying out bank intermediation functions, especially the collection and distribution of funds. The three components used are based on capital, asset quality, and liquidity aspects. The capital aspect is measured by Capital Adequacy Ratio (CAR), which states that if the value of the capital level is very low below the minimum value, it tends to cause a business loss that results in bankruptcy, so that it can endanger the safety of the customer's money. The asset quality aspect is measured by Non-Performing Loan (NPL), which states that high credit risk levels will reduce operating profit. The liquidity aspect is measured by Loan to Deposit Ratio (LDR), which states that the high bank's ability to distribute credit can increase customer confidence in the bank. In this research, the bank performance measurement indicators are measured by CAR and NPL.

Based on the previous research by Praja \& Hartono (2018), LDR has no effect on ROA. Yuttama (2019), Praja \& Hartono (2018), Ambarawati \& Abundanti (2018) state that the Capital Adequacy Ratio has a positive influence on Return on Assets, in contrast to the research done by Paleni et. Al. (2017), showing that Capital Adequacy Ratio has a negative and significant influence on Return on Assets. However, Widyastuti et. al. 
(2017) and Fajari \& Sunarto (2017) found that Capital Adequacy Ratio has no influence on the Return on Assets, because the number of capital is not invested in credit, but is invested in company assets.

Based on previous research, Praja \& Hartono (2019) and Paleni et. al. (2017) observed that Non-Performing Loan has a positive influence on Return on Assets, in contrast to research from Ambarawati \& Abundanti (2018), which states that Non-Performing Loan have a negative influence on Return on Assets. However, Widyastuti et. al. (2017) found that Non-Performing Loan had no significant influence on Return on Assets. Based on the descriptive above, there are three research problems proposed: (1) Does an increase in Capital Adequacy Ratio make the Return on Assets rise?, (2) Does an increase in Non-Performing Loan make Return on Assets decrease?, (3) Do Capital Adequacy Ratio and Non-Performing Loan simultaneously affect Return on Assets? The objectives of this research are: (1) to determine the influence of Capital Adequacy Ratio on Return on Assets, (2) to determine the influence of Non-Performing Loan on Return on Assets, (3) to determine the simultaneous influence of Capital Adequacy Ratio and NonPerforming Loan on Return on Assets. This research is expected to give contribution to the prospective customer in making decision of choosing the reputable bank with good financial performance and to the bank in considering Capital Adequacy Ratio and Non-Performing Loan as factors that affect bank's profitability.

\section{LITERATURE REVIEW}

\section{Signalling Theory}

The signalling theory is a theory suggesting that there is a source of information provided between managers and potential investors. This theory provides an overview of how for important the company is to present information to the public in the form of financial reports, information related to company policies, and others that can be disclosed by the manager (Syahid, 2016).

\section{Anticipated Income Theory}

Anticipated income theory is a theory suggesting that all allocated funds can be shown in a sector that brings benefits to the bank's business in the future (Widyanty \& Oktasari, 2020).

\section{Profitability}

Profitability Ratio is an important indicator in measuring financial stability in bank institutions that play an important role in economic continuity. Therefore, the bank is required to carry out operational activities from the distribution of funds in the form of credit into productive investment, so that together with the high profitability of the excess funds owned, the financial stability in the bank is maintained (Kawshala \& Pandhitarathna, 2017). The profitability ratio can be measured 
Djaya, N. K., \& Yanuarti, I.

THE INFLUENCE OF CAPITAL ADEQUACY RATIO AND NON-PERFORMING LOAN ON PROFITABILITY OF COMMERCIAL BANKS LISTED ON THE INDONESIA STOCK EXCHANGE IN 2017 - 2019

using Return on Assets, Return on Equity and Net Interest Margin. Return on Assets focuses on the bank's business performance which is implemented as a whole in obtaining profits, while Return on Equity focuses on the use of shareholder wealth to benefit (Mehta \& Bahvani, 2017). Net Interest Margin focuses on bank capabilities that operate on greater interest value than interest expenses in generating the net interest benefits obtained (Angori et. al., 2019). In this research, we are focusing on Return on Assets.

Return on Assets is an indicator that shows the ability of the bank management to obtain efficient profits originating from the assets owned by the bank's business (Ariyadasa et. al., 2016). This ratio also shows how much net profit is produced from the amount of funds embedded from the company's assets, so that with a high ratio value, the bank's business will be increasingly profitable (Kumbirai \& Webb, 2010, Javaid \& Alalawi, 2018). Maiti \& Jana (2017) also agreed that the greater the ROA ratio obtained, the banking effort and performance of the company are higher in obtaining profits. This ratio can be calculated by the following formula (Muraina, 2018).

\section{Return on Assets $=\frac{\text { Net Income }}{\text { Total Assets }}$}

where,

Net Income $=$ Profit after Tax

Total Assets $=$ The amount of company assets in total

\section{Capital Adequacy Ratio}

Capital Adequacy is used as a forecast of whether the capital owned by the bank is enough to cover up a risk of losses (Agbeja et. al., 2015). In this case, the ratio is based on the capital adequacy category, which is the amount of capital that can be managed by the bank as a reserve of risk assets, which aims to avoid the occurrence of loss problems. The adequacy of capital collected is very important in maintaining the health of the banking business, which is aiming to avoid the risk of loss and maximizing the profitability level of the business. CAR shows how capable the company is to minimize unexpected losses by measuring the amount of capital that must be determined by the bank as referred to minimize the risk of risk-weighted assets (Ali, 2020). This ratio is an important indicator, for the bank, of a large loss risk that can threaten the existence of the bank in carrying out operational activities. The high value of risk-weighted assets, reflecting being difficult for the bank to obtain sources of funding, increases the cost of capital, and inhibit the profitability of the bank. And vice versa, if the 
bank has a large capital, then the risk of struggle will occur lower and tends to maintain good profitability (Mehta \& Bhavani, 2017).

According to Bank Indonesia Regulation No. 15/12 / PBI / 2013, the bank must provide sufficient capital as a reserve of risk assets with a minimum value of at least $8 \%$ of the risk-weighted asset. With the standard of capital adequacy set, if the capital collected by the bank is greater, the banking business is able to minimize the risk of losses and be able to carry out these operational activities, so that they can increase business profitability. Capital Adequacy Ratio (CAR) can be calculated in the following manner (Saif-Alyousfi et. al., 2017).

$$
\text { Capital Adequacy Ratio }=\frac{\text { Capital }}{\text { Risk Weighted Assets }}
$$

where,

Capital $\quad=$ Tier I (core capital) + Tier II (supplementary capital)

Risk Weighted Assets $=$ The number of bank assets that are weighted according to credit, market, and operational risks

\section{Non-Performing Loan}

Risk is something faced by the bank in carrying out operational activities to obtain income. In carrying out operational activities such as credit distribution, this risk arises when customers cannot repay loans that are distributed instantly (Ramadhanti et. al., 2019). Troubled credit shows the problems faced by borrowers in continuing credit payments that result in default, where there is a very small possibility for credit repayment (Singh et. al., 2021). Because credit is one of the factors that affect the bank's income and expenses, it means the credit can be a source of profit for the bank effectively or it can be a source of losses for the bank (Putranto et. al., 2017). Factors that affect credit risk come from internal and external sources. When viewed according to internal factors, it relates to the existence of policies and regulations imposed in the bank's efforts such as expansive credit policies and also weakening the surveillance system for lending. And based on external factors, there is a decrease in economic activity and high lending given, debtor failure in making payments, and also disaster (Syahid, 2016).

Credit risk is indicated by NPL ratio that is used as a measurement of the bank's business capabilities in managing the risk of problematic loans (Ramadhanti et. al., 2019). Non-Performing Loan (NPL) is a comparison between problematic loans and credit given to third parties who do not include other parties. Based on Bank Indonesia Regulation No. 18 / 14 / PBI / 2016, banks must meet NPL ratio of less than $5 \%$. If this ratio is lower, the health level owned by the bank's business is getting better and increasing 
Djaya, N. K., \& Yanuarti, I.

THE INFLUENCE OF CAPITAL ADEQUACY RATIO AND NON-PERFORMING LOAN ON PROFITABILITY OF COMMERCIAL BANKS LISTED ON THE INDONESIA STOCK EXCHANGE IN 2017 - 2019

profitability. However, when NPL ratio exceeds $5 \%$, the soundness level owned by the business is not good and tends to reduce the level of profitability of the bank's business. NPL ratio is calculated by the following formula (Singh et. al., 2021).

$$
\text { Non Performing Loan }=\frac{\text { Non Performing Loan }}{\text { Total Loan }}
$$

where,

Non-Performing Loan $=$ Number of Non-Performing Loan caused by the existence of bad debt

Total Loan $\quad=$ Total loans distributed to third parties before reducing loss reserves

\section{The Influence of Capital Adequacy Ratio on Return on Assets}

The results of the research conducted by Budhatoki \& Rai (2020) found that Capital Adequacy Ratio had a significant influence on Return on Assets. Kawshala \& Panditharathna (2017) found that Capital Adequacy Ratio had a positive influence on Return on Assets. This shows that the high ratio of capital adequacy will be able to increase the profitability of the bank (Kossoh et. al., 2017. Based on that explanation, it can be proposed that:

$H A_{1}$ : Capital Adequacy Ratio has a positive influence on Return on Assets

\section{The Influence of Non-Performing Loan on Return on Assets}

Yuttama (2019), and Paramita \& Dana (2019), found that Non Performing Loan had a negative influence on Return on Assets. This means that the high value of Non-Performing Loan will reduce the value of Return on Assets, because the higher NPL tends to increase the credit risk of the bank, so it will decrease the level of profitability of the bank (Kossoh et. al., 2017). Based on the result of previous research, it can be proposed that:

$\mathrm{HA}_{2}$ : Non-Performing Loan has a negative influence on Return on Assets.

\section{Research Model}

The research model can be observed in the image below. 


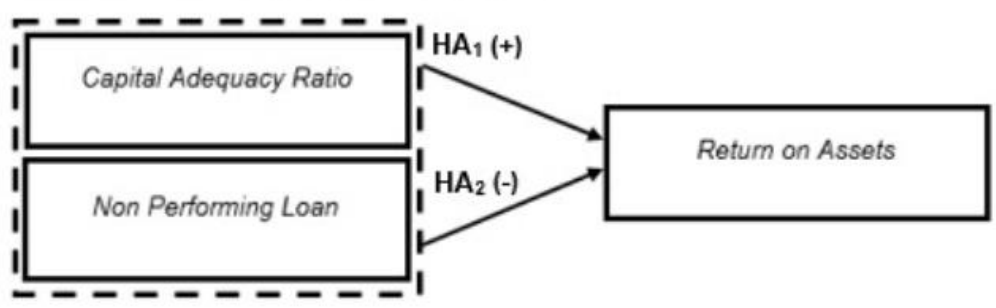

\section{FIGURE 1. RESEARCH FRAMEWORK}

Source: The Authors

\section{RESEARCH METHODS}

\section{Data Collection Techniques}

This research uses secondary data, which is already available and the researchers no longer need to collect the data. This data is taken from the annual financial statements of the commercial bank companies listed on the Indonesia Stock Exchange (IDX) in the 2017 - 2019 period. This data is accessed through the Indonesia Stock Exchange site, namely www.idx.co.id.

\section{Sampling Techniques}

The sampling technique used is judgment sampling which was classified as purposive sampling, because the technique was applied to samples based on the criteria needed to provide information sources. In this case, the criteria needed in determining research samples is consisting of:

a. Bank companies listed on the Indonesia Stock Exchange.

b. Companies that are classified as commercial banks in 2017 - 2019.

C. The bank companies' published audited financial statements in $2017-2019$

d. Reports issued by commercial banks that have a positive earning for three consecutive years.

TABLE 1. DETERMINATION OF SAMPLE CRITERIA

\begin{tabular}{|c|c|c|}
\hline Number & Bank Criteria & Total \\
\hline 1. & Bank companies listed in the Indonesia Stock Exchange & 43 \\
\hline 2. & Bank companies that are classified as commercial banks & 38 \\
\hline 3. & Bank companies that issue audited financial statements in 2017 - 2019 & 38 \\
\hline 4. & Commercial bank companies that have positive earning for three years & 26 \\
\hline
\end{tabular}

Source: The Authors 
Djaya, N. K., \& Yanuarti, I.

THE INFLUENCE OF CAPITAL ADEQUACY RATIO AND NON-PERFORMING LOAN ON PROFITABILITY OF COMMERCIAL BANKS LISTED ON THE INDONESIA STOCK EXCHANGE IN 2017 - 2019

In accordance with the criteria described in detail, the number of commercial bank samples used for research is 26 companies.

\section{Data Analysis Techniques}

\subsection{Multiple regression analysis}

This research used multiple regression analysis, which is a statistical method that aims to test the relationship between one dependent variable and one or more independent variables (Ghozali, 2013). This study aims to test the significant influence of independent variables, namely Capital Adequacy Ratio and Non-Performing Loan on dependent variable, namely Return on Assets. The equation of multiple regression functions in this study is the following:

$$
\mathrm{ROA}=\alpha+\beta_{1} \mathrm{CAR}+\beta_{2} \mathrm{NPL}+e
$$

where :

$$
\begin{array}{ll}
\mathrm{ROA} & =\text { Return on Assets } \\
\mathrm{A} & =\text { Regression Constant } \\
\beta_{1} \beta_{2} \beta_{3} & =\text { Regression Coefficient } \\
\mathrm{CAR} & =\text { Capital Adequacy Ratio } \\
\mathrm{NPL} & =\text { Non Performing Loan } \\
e & =\text { error }
\end{array}
$$

\subsection{The simultaneous significance test (F-test)}

In order to test the hypotheses, there are two determinations as follows:

1) If the $\mathrm{F}$ value is greater than the $\mathrm{F}$-table, then $\mathrm{H}_{0}$ can be rejected at $5 \%$ significance level. It means all independent variables have the influence on the dependent variables.

2) If the $F$ value is smaller than the $F$-table, it means that all independent variables have no influence on the dependent variables.

\subsection{The individual significance test (t-test)}

In order to test the hypotheses, there are two determinations as follows: 
1) If the $t$ value is greater than the $t$-table, then $\mathrm{H}_{0}$ can be rejected at $5 \%$ significance level. It means all independent variables have the influence on the dependent variables individually.

2) If the $t$ value is smaller than the t-table, it means that all independent variables have no influence on the dependent variables individually.

\section{FINDINGS AND RESULTS}

The results of the normality test using Kolmogorov-Smirnov showed a p-value of 0.364 and it confirmed that the data is normally distributed (Ghozali, 2013). The result of the multicollinearity test shows that the regression model has no multicollinearity between independent variables, which results show that the tolerance value is greater than 0.10 and the VIF value is smaller than 10 (Ghozali, 2013).

\section{TABLE 2. THE RESULTS OF THE MULTICOLLINEARITY TEST}

\begin{tabular}{|c|c|c|c|}
\hline \multirow{2}{*}{ Model } & \multicolumn{2}{c|}{ Collinearity Statistics } \\
\cline { 3 - 4 } 1 & Tolerance & VIF \\
\hline \multirow{2}{*}{1} & CAR & .998 & 1.002 \\
\cline { 2 - 4 } & NPL & .998 & 1.002 \\
\hline \multicolumn{3}{|c|}{ a. Dependent Variable: ROA } \\
\hline \multicolumn{2}{|c|}{ Source: The Authors }
\end{tabular}

The results of the autocorrelation test confirmed that the regression model has no autocorrelation, indicated by the value of Durbin-Watson of 0.830 which is between -2 as the lower limit and +2 as the upper limit (Santoso, 2019). The regression model also has no heterocedasticity, which is shown by the data that is spread randomly on the scatterplot graph, both above and below the number 0 on the $Y$ axis and do not form a regular pattern.

The coefficient of determination as shown by the Adjusted $R^{2}$ is 0.119 . It means that only $11.9 \%$ change in Return on Assets (ROA) can be explained by Capital Adequacy Ratio (CAR) and Non-Performing Loan (NPL). The remaining $88.1 \%$ is explained by other variables which are not included in this research model. The standard error of estimate is 0.00751 , which is relatively small, meaning that the regression model is appropriate in predicting the dependent variable (Ghozali, 2013).

TABLE 3. THE COEFFICIENT OF DETERMINATION 
Djaya, N. K., \& Yanuarti, I.

THE INFLUENCE OF CAPITAL ADEQUACY RATIO AND NON-PERFORMING LOAN ON PROFITABILITY OF COMMERCIAL BANKS LISTED ON THE INDONESIA STOCK EXCHANGE IN 2017 - 2019

\begin{tabular}{|c|r|r|r|r|}
\hline Model & $\mathrm{R}$ & $\begin{array}{c}\mathrm{R} \\
\text { Square }\end{array}$ & $\begin{array}{c}\text { Adjusted R } \\
\text { Square }\end{array}$ & $\begin{array}{c}\text { Std. Error of } \\
\text { the Estimate }\end{array}$ \\
\hline 1 & $.376^{\mathrm{a}}$ & .142 & .119 & .00751 \\
\hline
\end{tabular}

a. Predictors: (Constant), NPL, CAR

b. Dependent Variable: ROA

Source: The Authors

The statistical test results indicates that the $F$ value of the regression model is 6.191 with a significance value ( $p$-value) of 0.003 . This significance value is below 0.05 , which states that the independent variables consisting of Capital Adequacy Ratio (CAR) and Non-Performing Loan (NPL) have influence on the dependent variable, namely Return on assets (ROA) simultaneously.

TABLE 4. THE RESULTS OF STATISTICAL F- TEST

\begin{tabular}{|c|l|r|r|r|r|r|}
\hline \multicolumn{2}{|c|}{ Model } & Sum of Squares & df & Mean Square & F & Sig. \\
\hline \multirow{3}{*}{1} & Regression & .001 & 2 & .000 & 6.191 & $.003^{\mathrm{b}}$ \\
\cline { 2 - 7 } & Residual & .004 & 75 & .000 & & \\
\cline { 2 - 7 } & Total & .005 & 77 & & & \\
\hline
\end{tabular}

a. Dependent Variable: ROA

b. Predictors: (Constant), NPL, CAR

Source: The Authors

In the result of the t-test, all of the independent variables have $p$-value below 0.05 , meaning that each of the independent variables have influence on the dependent variable.

TABLE 5. THE RESULTS OF STATISTICAL T-TEST

\begin{tabular}{|c|c|c|c|c|c|c|}
\hline & \multirow[t]{2}{*}{ Model } & \multicolumn{2}{|c|}{ Unstandardized Coefficients } & $\begin{array}{l}\text { Standardized } \\
\text { Coefficients }\end{array}$ & \multirow[t]{2}{*}{$t$} & \multirow[t]{2}{*}{ Sig. } \\
\hline & & B & Std. Error & Beta & & \\
\hline \multirow{2}{*}{1} & (Constant) & .017 & .003 & & 5.598 & .000 \\
\hline & CAR & .005 & .010 & .056 & .519 & .605 \\
\hline
\end{tabular}




\begin{tabular}{|l|ll|l|l|l|l|}
\hline \multicolumn{1}{|l|}{ NPL } & -.190 & .055 & -.370 & -3.453 & .001 \\
\hline \multicolumn{2}{|l}{ a. Dependent Variable: ROA } \\
\hline
\end{tabular}

Source: The Authors

Based on table above, CAR has the coefficient of 0.005 which indicates that any increase in the CAR value of $1 \%$, then ROA will increase by $0.5 \%$. CAR variable has t-value of 0.519 with $p$-value of 0.605 , which is greater than 0.05 , and the decision is rejecting $H_{A}$. It means that CAR has no influence on ROA. The coefficient of NPL is -0.19 , meaning that any increase in NPL value of $1 \%$, will lower ROA by $19 \%$. The NPL variable has a $t$ value of $-3,453$ with a $p$-value of 0.001 , which is a smaller value than 0.005 . This shows that NPL has a negative and significant influence on ROA, so the decision taken is $\mathrm{HA}_{2}$ which is accepted. The regression equation model in this research can be obtained as follows:

$$
\mathrm{ROA}=0,017+0,005 \mathrm{CAR}-0,190 \mathrm{NPL}+e
$$

\section{DISCUSSION}

\section{The Influence of Capital Adequacy Ratio on Return on Assets}

The results of this study are consistent with the affirmations of Widyastuti et. al. (2017) that Capital Adequacy Ratio has no influence on the Return on Assets, because the number of capital is not invested in credit, but is invested in company assets. This research is also consistent with the affirmations of Fajari \& Sunarto (2017), as the CAR has no influence on ROA, which is due to the large amount of funds that are not distributed to third parties in the form of credit, so it tends to reduce the level of profitability of the banks.

Based on the results of the above research, it can be concluded that higher CAR ratio is not followed by higher profitability, because the amount of capital is not being used efficiently for credit distribution to third parties. It can be shown from various companies, such as PT Bank Rakyat Indonesia Tbk (BBRI) which has a CAR ratio increased from $21.21 \%$ in 2018 to $22.55 \%$ in 2019 , but the ROA has decreased by $0.07 \%$ from 2018 to 2019. It was also the same with PT Bank Central Asia (BBCA) which in 2018, the CAR ratio was $23.95 \%$ and $24.64 \%$ in 2019 , but ROA decreased by $0.02 \%$ from 2018 to 2019 . Furthermore, PT Bank Mandiri Tbk (BMRI), had the CAR ratio in 2018 decreased by $0.68 \%$ from $21.64 \%$, in 2017 to $20.96 \%$, but ROA increased by $1.91 \%$ from 2017 to 2018 . For PT Bank Negara Indonesia (BBRI), the CAR value in 2019 increased to $19.73 \%$ from the previous year value of $18.50 \%$. However, the value of the ROA in 2019 decreased from $1.87 \%$ to $1.83 \%$. 


\section{THE INFLUENCE OF CAPITAL ADEQUACY RATIO AND NON-PERFORMING LOAN ON PROFITABILITY OF COMMERCIAL BANKS LISTED ON THE INDONESIA STOCK EXCHANGE IN 2017 - 2019}

\section{The Influence of Non-Performing Loan on Return on Assets}

The results of this research agree with Ambarawati \& Abundanti (2018) stating that high NPL will burden the losses borne by the banks, reducing the level of profitability. This was supported by research of Yuttama (2019) which stated that the difficulty experienced by the bank in minimizing the occurrence of bad loans, resulted in reducing the level of profitability. It is also supported by Paramita \& Dana (2019), that the high NPL will be followed by lower ROA due to losses that must be borne by the bank in carrying out operational activities.

PT Bank Rakyat Indonesia (BBRI), which had an increase in NPL by 1.50\% and 1.63\% in 2018 and 2019 respectively, but the ROA had decreased by $2.50 \%$ and $2.43 \%$ in 2018 and 2019 respectively. PT Bank Negara Indonesia (BBNI) had an increase in NPL value by 3.55\% from 2018 to 2019, but the value of ROA decreased by $1.83 \%$.

\section{CONCLUSION}

Based on the discussion above, it can be concluded that Capital Adequacy Ratio (CAR) has a positive and insignificant influence on Return on Assets (ROA). It means that the large or small level of capital owned by the bank's business does not affect the level of profitability. Non-Performing Loan (NPL) has a negative and significant influence on Return on Assets (ROA), meaning that the greater value of NPL will lower the level of profitability. If it is associated with signalling theory, it shows the health level of the bank, which is measured through aspects of asset quality such as risk credit risk. In this aspect, if the risk of Non-Performing Loan is high, as the customer makes credit payment exceeding the specified time limit due to timely default, it tends to reduce the profitability of the bank's business. If it is associated with anticipated income theory, it indicates that all funds allocated will bring profits if the credit paid can be carried out by the customer in a timely manner. However, if the customer credit payment is not on time and exceeds the specified time limit, it tends to reduce the level of profitability of the bank's business.

\section{REFERENCES}

Agbeja, O., Adelakun, O. J., \& Olufemi, F. I. (2015). Capital Adequacy Ratio and Bank Profitability in Nigeria: A Linear Approach. International Journal of Novel Research in Marketing Management and Economics, 2(3): $91-99$.

Ali, A. M. (2020). The impact of economic blockade on the performance of Qatari Islamic and conventional banks: a period-and-group-wise comparison. ISRA International Journal of Islamic Finance, 12(3): 419 - 441, doi.org/10.1108/IJIF-04-2020-0083.

Ambarawati, I. G. A. D. \& Abundanti, N. (2018). Pengaruh Capital Adequacy Ratio, Non Performing 
Djaya, N. K., \& Yanuarti, I.

THE INFLUENCE OF CAPITAL ADEQUACY RATIO AND NON-PERFORMING LOAN ON PROFITABILITY OF COMMERCIAL BANKS LISTED ON THE INDONESIA STOCK EXCHANGE IN 2017 - 2019

Loan, Loan to Deposit Ratio terhadap Return on Assets. E-Jurnal Manajemen Unud, 7(5): $2410-2441$.

Angori, G., Aristei, D., \& Gallo, M. (2019). Determinants of Banks' Net Interest Margin: Evidence from the Euro Area during the Crisis and Post-Crisis Period. Sustainability, 11(3785): 1 - 20. doi.org/10.3390/su11143785.

Ariyadasa, C., Selvanathan, E. A., Siddique, M. A. B., \& Selvanathan, S. (2016). On the Profitability of Commercial Banks: the Sri Lankan case. Applied Economics, pp. 1 - 11. doi.org/10.1080/00036846.2016.1231909.

Bank Indonesia Regulation Number 15/12/PBI/2013 about Kewajiban Penyediaan Modal Minimum Bank Umum.

Bank Indonesia Regulation Number 18/14/PBI/2016 about Giro Wajib Minimum Bank Umum dalam Rupiah and Valuta Asing bagi Bank Umum Konvensional.

Budhatoki, P.B. \& Rai, C. K. (2020). The Effect of Specific Factors on Bank Profitability: Evidence from Nepalese Banks. Journal of Economics and Business, 3(1): 82 - 89.

Fajari, S. \& Sunarto (2017). Pengaruh CAR, LDR, NPL, BOPO terhadap Profitabilitas Bank. Seminar Nasional Multi Disiplin Ilmu Unisbank, 853 - 862.

Ghozali, I. (2013). Aplikasi Analisis Multivariate dengan Program IBM SPSS 23. Semarang: Badan Penerbit Universitas Diponegoro.

Haryanto, S. (2016). Profitability Identification of National Banking through Credit, Capital, Capital Structure, Efficiency, and Risk Level. Jurnal Dinamika Manajemen, 7(1): 11 - 21.

Javaid, S. \& Alalawi, S. (2018). Performance and Profitability of Islamic Banks in Saudi Arabia: An Empirical Analysis. Asian Economic and Financial Review, 8(1): 38 - 51.

10.18488/journal.aefr.2018.81.38.51.

Kawshala, H. \& Pandhitarathna, K. (2017). The Factors Effecting on Bank Profitability. International Journal of Scientific and Research Publicatioins, 7(2): 212 - 216.

Kossoh, A. M., Mangantar, M., \& Ogi, I. W. J. (2017). Pengaruh Non Performing Loan (NPL), Capital Adequacy Ratio (CAR), Loan to Deposit Ratio (LDR) terhadap Profitabilitas pada Bank Pembangunan Daerah (BPD) Se-Indonesia tahun 2011 - 2015. Jurmal EMBA : Jurnal Riset Ekonomi, Manajemen, Bisnis dan Akuntansi, 5(3) : 2721 - 2730.

doi.org/10.35794/emba.v5i3.17150.

Kumbirai, M. and R. Webb, 2010. A Financial Ratio Analysis of Commercial Bank Performance in South Africa. African Review of Economics and Finance, 2(1): 30-53.

Maiti, A. \& Jana, S. K. (2017). Determinants of Profitability of Banks in India: A Panel Data Analysis. Scholars Journal of Economics, Business and Management, 4(7): 436 - 445, doi: 10.21276/sjebm.

Majidi, Z. (2017). Analisis Pengaruh CAR, NPL, dan LDR terhadap Profitabilitas pada Perusahaan Perbankan yang Listing di BEI (2014 - 2016). Jurnal IImiah Riset Akuntansi, 100 - 114.

Mehta, A. \& Bhavani, G. (2017). What Determines Banks' Profitability? Evidence from Emerging Markets-the Case of the UAE Banking Sector. Accounting and Finance Research, 6(1): 77-88. 10.5430/afr.v6n1p77. 


\section{THE INFLUENCE OF CAPITAL ADEQUACY RATIO AND NON-PERFORMING LOAN ON PROFITABILITY OF COMMERCIAL BANKS LISTED ON THE INDONESIA STOCK EXCHANGE IN 2017 - 2019}

Muraina, S.A. (2018). Determinants of Listed Deposit Money Banks' Profitability in Nigeria. International Journal of Finance and Banking Research, 4(3): 40 - 56.

Paramita, P. K. and Dana, I. M. (2019). Pengaruh Capital Adequacy Ratio, Non Performing Loan, dan Loan to Deposit Ratio terhadap Profitabilitas. EJurnal Manajemen, 8(2) : 7633 - 7660.

Praja, N. B. A. \& Hartono, U. (2018). Pengaruh Ukuran Perusahaan, Capital Adequacy Ratio, Loan to Deposit Ratio, dan Non Performing Loan terhadap Profitabilitas Bank Umum Swasta Nasional Devisa yang Terdaftar di Indonesia Periode 2012 - 2016. Jurnal IImu Manajemen, 7(1): 1-12.

Putranto, A. A. \& Kristanti, F. T. (2017). Capital Adequacy Ratio, Loan to Deposit Ratio, dan NonPerforming Loan terhadap Profitabilitas. Jurnal Riset Akuntansi Kontemporer (JRAK), 9(2): 88-93

Ramadhanti, C., Marlina, \& Hidayati, S. (2019). The Effect Capital Adequacy, Liquidity and Credit Risk to Profitability of Commercial Banks. Journal of Economics, Business, and Government Challenges, 2(1): $71-78$.

doi.org/10.33005/ebgc.v2i1.66.

Saif-Alyousfi, A. Y. H, Saha, A., \& Md-Rus, R. (2017). Profitability of Saudi Commercial Banks: A Comparative Evaluation between Domestic and Foreign Banks using Capital Adequacy, Asset Quality, Management Quality, Earning Ability and Liquidity Parameters. International Journal of Economics and Financial Issues, 7(2): 477 - 484.

Santoso, S. (2019). Mahir Statistik Parametrik. Jakarta : PT Elex Media Komputindo.

Singh, S. K., Basuki, \& Setiawan, R. (2021). The Effect of Non-Performing Loan on Profitability: Empirical Evidence from Nepalese Commercial Banks. Journal of Asian Finance, Economics and Business, 8(4): 709 - 716.

Syahid, D.C.N. (2016). Pengaruh Faktor Eksternal dan Internal terhadap Kredit Bermasalah serta Dampaknya terhadap Cadangan Kerugian Penurunan Nilai Menurut PSAK 55. Perbanas Review, 2 (1).

Widyanty, W. \& Oktasari, D. P. (2020). Financial Ratio Analysis as a Prediction Tool of Bankruptcy on Banking Companies Listed in Indonesia Stock Exchange. Advances in Economics, Business and Management Research, 120: 180 - 184.

10.7176/EJBM

Widyastuti, U., Purwana, E. S. Dedi, \& Zulaihati, S. (2017). Internal Determinants of Commercial Bank Profitability In Indonesia. Mediterranean Journal of Social Sciences, 8(3): 219 - 224.

10.5901/mjss.2017.v8n3p219.

Yuttama, F. R. (2019). Influence of Capital, Liquidity, Operating Efficiency, and Lock Credit on Profitability with Inflation as Moderation. International Conference on Rural Development and Entrepreneurship 2019: Enhancing Small Business and Rural Development Toward Industrial Revolution 4.0, 5(1): 810 - 815.

bps.go.id

ekonomy.okezone.com

finansial.bisnis.com

keuangan.kontan.co.id

ojk.go.id 